\title{
Industry, War and Stalin's Battle for Resources: The Arctic and the Environment
}

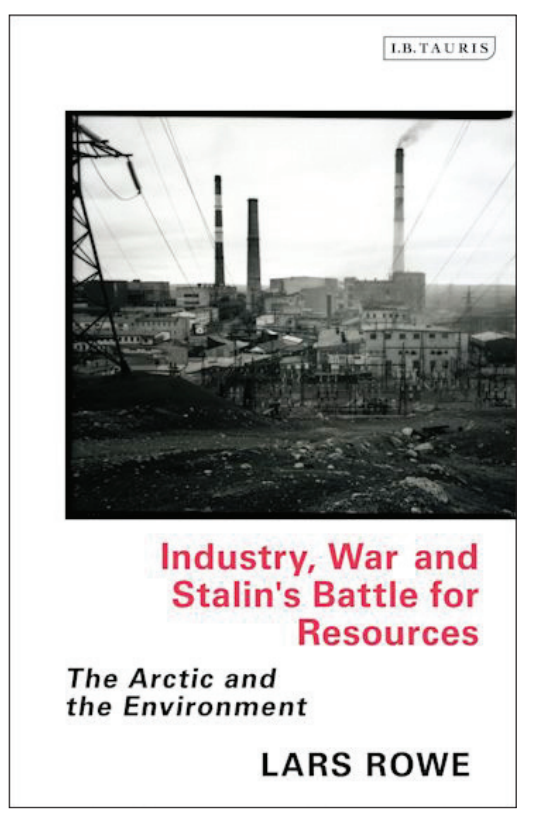

Lars Rowe

London: I.B. Tauris 2021

240 sider. ISBN: 9781784537951

Anmeldt af Niels Bo Poulsen [ph.d., institutchef ved Forsvarsakademiet, København, nipo@fak.dk]

Anmeldte bog føjer sig til rækken af regional- og bystudier vedrørende Stalin-perioden. Andre bidrag er eksempelvis Stephen Kotkins Magnetic Mountain: Stalinism as a Civilization fra 1995, Per Brodersens Die Stadt im Westen: Wie Königsberg Kaliningrad wurde fra 2008 og Lennart Samuelsons Tankograd: The Formation of a Soviet Company Town: Cheliabinsk 1900s-1950s fra 2011. Lars Rowes undersøgelse omhandler dog ikke en by eller en egn som sådan, men derimod det industrikompleks til udvinding af de rige nikkelforekomster i Petsamo-/Pechengaområdet, der blev påbegyndt af Finland i mellemkrigstiden, og som for alvor udbyggedes, efter at Sovjetunionen i 1944/1947 indlemmede landstriben. Rowes studie bliver dermed en undersøgelse af en arktisk grænseegn med strategiske råstoffer. Således får vi indblik i dynamikken mellem kommercielle ambitioner og statssikkerhed fra mellemkrigsperioden og frem til cirka 1950 - det er i hvert fald, hvad der tilbydes af forfatteren i indledningen (s. 1-2), og et langt stykke hen ad vejen - men ikke helt - det, som bogen blandt andet tilbyder læseren. 
Industry, War and Stalin's Battle for Resources er disponeret i fire hovedkapitler, hvortil kommer en introduktion og en konklusion. Først undersøges årene frem til vinterkrigen - en periode, hvor Petsamo, der blev en del af Finland i 1920, havde betydning som en vigtig trafikåre. Med opdagelsen af de rige nikkelforekomster, hvilket skete kort efter Petsamos indlemmelse i Finland, fik området desuden begyndende kommerciel og strategisk betydning. Der blev opbygget et nikkel-kombinat af den amerikansk-canadiske INCO-koncern, som blandt andet søgte koncessionen for at sikre sig en gunstig stilling som leverandør af nikkel til IG Farben. I det næste kapitel studeres sekvensen af krige og kriser (1939-1945). Krigen medførte blandt andet tysk kontrol med anlægget og næsten total destruktion af det, da de tyske styrker forlod Lapland. Derpå følger to kapitler, der handler om den sovjetiske overtagelse af området og den finske involvering $\mathrm{i}$ at genopbygge og udvide de af tyskerne ødelagte kraftværker og dæmninger, således at man igen kunne producere tilstrækkelig strøm til at drive nikkelproduktionen.

I Rowes velskrevne og kyndige bog er vægten lagt på sovjetperioden, som fylder omtrent 80 af bogens 160 sider. Det er særligt arkivalier fra Det Russiske Statslige Økonomiske Arkiv (RGAE), som bringes i spil i teksten, men også kildeudgivelser vedrørende tysk og russisk udenrigspolitik indgår i analysen, mens finske kilder og litteratur af sproglige årsager beklageligvis ikke er inddraget. Bogen hviler ikke på et teoretisk fundament, men er i højere grad redegørende og historisk-kildenært analyserende. Tættest på et teoretisk afsæt kommer man gennem en del referencer til den måde, hvorpå Stephen Kotkin i sit banebrydende studie af Magnitogorsk, Magnetic Mountain, studerede deltagerne i opbygningen af denne industriby som mennesker, der havde internaliseret de stalinistiske normer, samtidig med at de inden for disse rammer dygtigt forvaltede deres egne interesser. I modsætning til Kotkins værk er det dog ikke græsrodsperspektivet, som er i centrum hos Rowe. Historien fortælles top-down med fokus på de udenrigspolitiske og økonomiske hovedaktører, og det lokale perspektiv - som det blandt andet optræder gennem indberetninger fra en række sovjetiske embedsmænd - er sekundært, men ikke fraværende.

Rowe demonstrerer, hvordan Finland formåede at anvende nikkelforekomsterne til at balancere mellem stormagterne, dels før krigen, dels under krigen, hvor tyskerne overtog udvindingen, men koncessionen i princippet forblev i hænderne på det canadisk-amerikanske firma, som i årene før krigen havde opført et særdeles moderne anlæg i området. Denne del af bogen bygger dog primært på andres forskning, hvilket vel hænger sammen med fraværet af finske kilder. Den sovjetiske interesse for området meldte sig i foråret/sommeren 1940 efter et sovjetisk ekspertholds besigtigelse af området, mens det kortvarigt var besat under vinterkrigen. De udsendte mænd sendte Moskva en rapport, som både henledte opmærksomheden på de rige nikkelforekomster og på den canadiske koncessionshavers høje tekniske niveau. Herfra følger Rowe området særligt gennem sovjetiske kilder, men historien spoles hurtigt frem til den sovjetiske overtagelse af området i 1944. Det er 
genopbygningen af de af tyskerne ødelagte udvindings- og produktionsfaciliteter, som derpå står i højsædet, herunder i et spændende kapitel om, hvordan vandkraftudbygningen skete gennem anvendelse af finske og svenske firmaer i det område, som Finland i 1947 solgte til Sovjetunionen. Denne landstribe langs Paz-floden blev frem til færdiggørelsen af de sovjetiske vandkraftanlæg reelt en slags ingenmandsland, hvor den finske hovedentreprenør måtte anvende egne vagtmænd som en slags lokalt politi, da de sovjetiske myndigheder alene tog sig af grænsekontrollen. Det kom i den forbindelse til adskillige ildebrande, som dels accentuerede problemet med den manglende politimyndighed, dels gav den sovjetiske side bekymringer om mulig sabotage, uden at kilderne dog antyder, at sikkerhedsregimet blev afgørende strammet.

Rowe tegner gennem sammenvæuningen af disse forskellige perspektiver et billede af en række dårligt koordinerede sovjetiske aktører, hvilket blandt andet fører til den paradoksale situation, at transporten af finske varer til den højt prioriterede bygning af kraftværker langs Paz-floden fordyredes væsentligt, fordi transportopgaven af de sovjetiske myndigheder blev givet til et i Finland indregistreret sovjetisk firma, der dog ikke selv var opgaven voksen. Det uddelegerede derfor store dele af logistikken til et finsk firma, men tog sig højt betalt af sovjetiske midler for sin rolle som mellemmand. Samtidig viser Rowe, at der i høj grad var tale om et konstruktivt finsk-sovjetisk samarbejde, hvor blandt andet Moskvas mellemmand Boris Klesjko jævnligt skosede sin egen side for deres dispositioner og støttede finnerne i deres krav.

Man savner dog den finske side af sagen, idet bogen som allerede nævnt desværre ikke inddrager finske kilder. Det er en af svaghederne ved Rowes arbejde, og dertil må lægges, at man i det hele taget savner et lidt bredere perspektiv på tingene. Selv om det $\mathrm{i}$ indledningen hævdes, at sikkerhed og økonomi var sammenvævet i området, og at det er bogens formål at analysere disse to størrelser som koblede, finder man ikke en kildebaseret analyse af, hvordan den tidlige kolde krig påvirkede de sovjetiske dispositioner, eller hvordan vigtige institutioner som forsvaret og efterretnings- og sikkerhedsorganerne så på dette grænseområde op til NATO-landet Norge. Det er forståeligt, at det ikke er lykkedes Rowe at få adgang til relevante russiske arkiver på området, men det begrænser bogens udsagnskraft betydeligt og svækker hans eget anslag. Endelig kunne det forhold, at nikkel var et strategisk råstof af meget stor betydning, have givet Rowe anledning til at dykke lidt dybere ned i den generelle tyske interesse for Nordkalotten i mellemkrigstiden - en interesse, som drejede sig om adgangen til nikkel og svensk jernmalm, men som også handlede om tyske adgangsveje til Nordatlanten og om forhindring af en forestillet sovjetisk ekspansion mod vest. Ydermere havde emnet strategiske råstoffer fortjent en kort perspektivering til tilsvarende situationer, hvor småstater har besiddet væsentlige strategiske råmaterialer, som for eksempel Grønland i dag.

Bogen er et værdifuldt detailstudie, som særligt i forhold til sovjetisk økonomihistorie og samspillet mellem forskellige statslige institutioner leverer et 
selvstændigt bidrag til forskningen, ligesom den også tilbyder læseren væsentlige perspektiver på småstaten Finlands råderum og på, hvad besiddelsen af strategiske råstoffer betyder for et mindre lands sikkerhed. Den historiske synsvinkel medfører dog, at det på flere punkter ikke bliver til en dybdegående analyse af disse forhold, hvilket er lidt ærgerligt med tanke på en bred anvendelse af bogen. Det kan ligeledes undre, at forfatteren ikke i sin afslutning i lidt højere grad trækker sin historie frem til nutiden. 